\title{
Direct Observation of the Effect of Autoreceptors on Stimulated Release of Catecholamines from Adrenal Cells
}

\author{
Rong Zhou, Guoan Luo, and Andrew G. Ewing \\ Department of Chemistry, The Pennsylvania State University, University Park, Pennsylvania 16802
}

The direct effect of $\alpha_{2}$-autoreceptors was studied by measuring the effects of piperoxan, an $\alpha_{2}$-autoreceptor antagonist, and clonidine, an agonist on catecholamine exocytosis, from single bovine chromaffin cells in culture. Catecholamine release was elicited by stimulation with 100 $\mu \mathrm{M}$ nicotine and was monitored electrochemically with a carbon-fiber microelectrode placed adjacent to the cell. These electrodes allowed the number of exocytotic release events to be monitored and reported as total charge for release following a specific stimulus. Repeated stimulation with $\mathbf{1 0 0}$ $\mu \mathrm{M}$ nicotine showed that total release caused by the second exposure to nicotine was $32 \%$ of the first, and release caused by the third exposure to nicotine was $80 \%$ of the second. Total release of catecholamine increased significantly after application of $20 \mu \mathrm{M}$ piperoxan relative to a control application of balanced salt solution. Application of $20 \mu \mathrm{M}$ piperoxan alone did not cause release. After the cells were incubated in culture medium containing $20 \mu \mathrm{M}$ clonidine, a significant decrease in nicotine-stimulated catecholamine release was observed. These results confirm that there are autoreceptors on chromaffin cells and, when relatively high levels of catecholamine are released, the catecholamine stimulates the $\alpha_{2}$-autoreceptors, which inhibits subsequent release through a negative feedback mechanism. In addition to piperoxan, the sympathomimetic drug amphetamine also increases quantal release after application of nicotine. Amphetamine increases the extracellular concentration of catecholamine, and these data appear to indicate that at least part of the pharmacology of amphetamine might involve blocking catecholamine autoreceptors.

IKey words: $\alpha_{2}$-autoreceptors, catecholamines, adrenal medullary chromaffin cells, microelectrodes, piperoxan, clonidine, amphetamine]

The release of catecholamines to the extracellular synaptic cleft can bc regulated by several factors, which include presynaptic $\alpha_{2}$-autoreceptor activation (Starke, 1981). The released extra-

Received July 16, 1993; revised Sept. 22, 1993; accepted Oct. 7, 1993.

This work was supported by grants from the Office of Naval Research and the National Science Foundation. A.G.E is a Camille and Henry Dreyfus Teacher Scholar. We would like to acknowledge Ta Kung Chen for helpful discussions about electrochemistry and exocytosis and Dr. David Sulzer for advice on the pharmacology of catecholamine autoreceptors.

Correspondence should be addressed to G. Ewing, Department of Chemistry, The Pennsylvania State University, 152 Davey Laboratory, University Park, PA 16802.

Copyright (c) 1994 Society for Neuroscience $0270-6474 / 94 / 142402-06 \$ 05.00 / 0$ cellular catecholamines act on presynaptic $\alpha_{2}$-autoreceptors to inhibit further catecholamine release (Starke, 1977; Westfall, 1977), and $\alpha_{2}$-autoreceptor agonists such as clonidine or guanfacine cause a suppression of locus cell firing and decrease the release of catecholamines (Pelayo et al., 1980; Cooper et al., 1991 ; Jackisch et al., 1992) whereas $\alpha_{2}$-autoreceptor antagonists such as piperoxan, yohimbine, and idazoxan reverse these inhibitory effects and increase release (Dennis et al., 1987; Abercrombie et al., 1988; Cooper et al., 1991).

Although some experiments have provided evidence about presynaptic mechanisms, it is not always possible to determine if the drugs affect the presynaptic terminals directly, or whether they act primarily on ncarby cells that then emit a second signal to the presynaptic terminals. This is particularly difficult to decide in tissue studies (Starke, 1981). Basically, there are two methods to study the interaction of neurotransmitters or drugs with cells. The first procedure is to determine the biological response of an intact isolated organ, such as the guinea pig ileum, to applied agonists or antagonists. The disadvantage to this procedure lies in the difficulty in discriminating between a large number of processes taking place before the drug interacts with the receptor. The second approach to studying receptors is to measure ligand binding to a homogenate or slice preparation. This technique became feasible with the development of ligands of a high specific radioactivity and a high affinity for the receptor (Cooper et al., 1991). Neither of these techniques eliminate postsynaptic effects. The use of amperometric monitoring of catecholamine exocytosis (Leszczyszyn et al., 1990), combined with the application of receptor agonists or antagonists, is a ncw method that can functionally identify autoreceptors directly, since there are no postsynaptic cells. The electrochemical measurements described here are spatially resolved to the singlecell level because of the size of the microelectrode sensor as well as the small volume of the applied chemical stimulus.

Adrenal medullary chromaffin cells were selected in the present study bccause they contain secretory granules that store the catecholamine hormones epinephrine and norepinephrine and they are similar to sympathetic neurons in neuroectodermal origin and biochemical function (Douglas, 1968; Viveros, 1975; Wightman et al., 1991). The cultured adrenal medullary cells have most of the properties of the cells in the intact gland (Wilson and Viveros, 1981; Livett, 1984). In the present work we used a new electrochemistry method (Leszczyszyn et al., 1990), combined with the application of an $\alpha_{2}$-autoreceptor antagonist, piperoxan, and an agonist, clonidine (Feldman and Quenzer, 1984; Cooper et al., 1991), to investigate the direct effect of $\alpha_{2}$ autoreceptors on nicotine-stimulated release of catecholamines from single adrenal medullary chromaffin cells. 


\section{Materials and Methods}

Cultured chromaffin cells. Primary cultures of bovine adrenal medullary chromaffin cells were prepared as previously described by Wilson and Viveros (1981) and Leszczyszyn et al. (1991) from fresh adrenal glands obtained from a local slaughterhouse. Experiments were performed at $37^{\circ} \mathrm{C}$ between days 4 and 6 of culture. The culture medium was removed and the cells were washed three times and then maintained in a balanced salt solution containing $150 \mathrm{~mm} \mathrm{NaCl}, 4.2 \mathrm{~mm} \mathrm{KCl,} 1.0 \mathrm{mM} \mathrm{NaH}_{2} \mathrm{PO}_{4}$, $11.2 \mathrm{~mm}$ glucose, $0.7 \mathrm{~mm} \mathrm{MgCl}_{2}, 2 \mathrm{~mm} \mathrm{CaCl}$, and $10 \mathrm{~mm}$ HEPES, adjusted to $\mathrm{pH}$ 7.4. $\mathrm{MgCl}_{2}$ was substituted for $\mathrm{Ca}^{2+}$-free solutions (Wightman et al., 1991). Chemical stimulations were performed with the desired agent dissolved in this solution.

Electrodes and voltammetric procedures. Working electrodes were prepared from $5-\mu \mathrm{m}$-diameter carbon fibers sealed in glass capillaries (Kelly and Wightman, 1986). The sensing tip of the electrode was polished at a $45^{\circ}$ angle on a micropipette beveler (World Precision Instruments, New Haven, CT). The reference electrode was a sodium-saturated calomel electrode (SSCE). Constant-potential amperometry was performed with a commercial potentiostat (EI-400, Ensman Instrumentation, Bloomington, IN). The applied potential was $650 \mathrm{mV}$. The output was connected to an A/D converter (Labmaster, Scientific Solutions, Solon, $\mathrm{OH}$ ) interfaced with a IBM personal computer.

Single chromaffin cell release experiments. The culture dish was placed on the stage of a microscope (IM35, Zeiss, Germany) resting upon a vibration isolation table (Kinetic Systems, Boston, MA). A working electrode was positioned over the top of a cell with a three-dimensional micromanipulator (Narishige, Tokyo, Japan). The electrode was manipulated so that it lightly touched a cell and then was retracted to the desired position (Wightman et al., 1991). Release of catecholamine from a single chromaffin cell was induced through short-duration $(3 \mathrm{sec}$ ) local applications of $100 \mu \mathrm{M}$ nicotine. Both the $\alpha_{2}$-autoreceptor antagonist piperoxan and agonist clonidine were used to show the effect of autoreceptors. The antagonist was examined following short-duration $(3 \mathrm{sec})$ local application of $100 \mu \mathrm{M}$ nicotine followed by local application of 20 $\mu \mathrm{M}$ piperoxan or balanced salt solution from two micropipettes attached to a two-channel pressure-application device (Picospritzer, General Valve Corporation, Fairfield, NJ). For the clonidine experiments, the cells were incubated for 30-90 min in the culture medium containing $20 \mu \mathrm{M}$ clonidine and secretion of catecholamine was elicited through local application of $100 \mu \mathrm{M}$ nicotine with $20 \mu \mathrm{M}$ clonidine. Typical tip dimensions of micropipettes were $10 \mu \mathrm{m}$. They were calibrated to deliver volumes of approximately $3 \mathrm{nl}$ at $1 \mathrm{sec}$. The micropipettes were positioned with a micropositioner (Zeiss) $30 \mu \mathrm{m}$ from the cell.

Data treatment. Transient current responses were evaluated by a peakdetection-integration algorithm. This program evaluated the current response by comparing the difference between consecutive data-point values, which is the first derivative of the original current data. When the difference between consecutive data points is greater than the peakdetection threshold (also called the noise threshold and is dependent on the experiment), then spikes were considered significant. Transient current responses measured in the amperometric mode were integrated with respect to time to determine the amount of charge in units of picocoulombs $(\mathrm{pC})$. The charge in each spike is related to the number of moles electrolyzed by Faraday's law.

Significance testing employed a two-side Student's $t$ test. Reported values are given with the standard error of the mean (SEM).

\section{Results}

Nicotine-stimulated catecholamine release from single cells The response of a single cell to a $3 \mathrm{sec}$ application of $100 \mu \mathrm{M}$ nicotine monitored by amperometry at a microelectrode is shown in Figure $1 \mathrm{~A}$. Current responses owing to the release of catecholamine from single granules are rapid and transient, as has been shown previously (Leszczyszyn et al., 1990, 1991; Wightman et al., 1991). The average spike area in our experiments was $0.7 \pm 0.02 \mathrm{pC}(n=218)$. Oxidation current for catecholamines at a carbon-fiber microelectrode placed adjacent to a single cell in $\mathrm{Ca}^{2+}$-free buffer is shown in Figure $1 B$. In this experiment, an injection of $100 \mu \mathrm{M}$ nicotine without $\mathrm{Ca}^{2+}$ in either the cell medium or injection pipette resulted in no current spikes. However, a second injection of nicotine with $2 \mathrm{~mm} \mathrm{Ca}^{2+}$
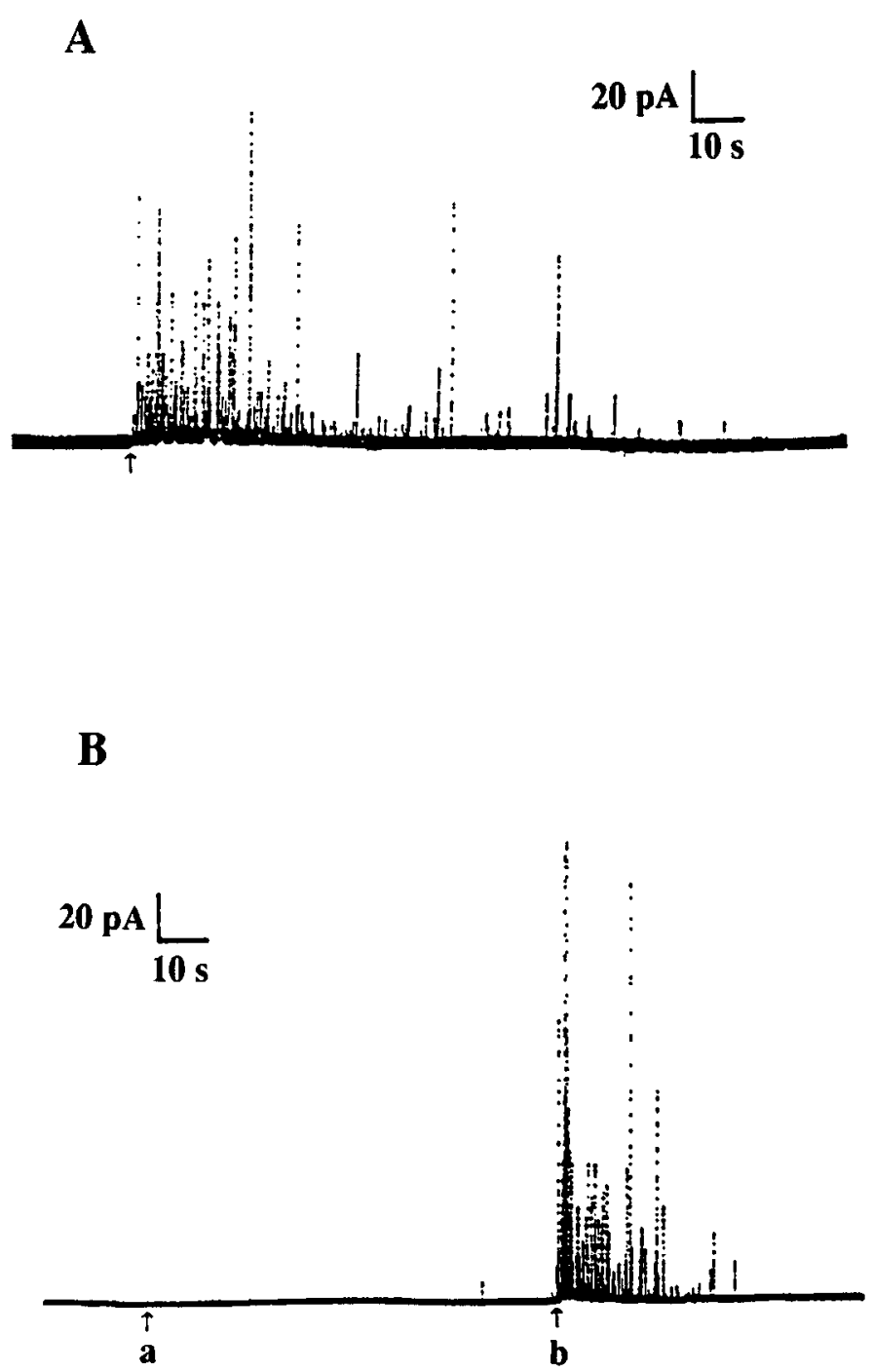

Figure 1. Current versus time at carbon-fiber electrodes placed outside single chromaffin cells. $A$, A $3 \mathrm{sec}$ application of $100 \mu \mathrm{M}$ nicotine was administered at the arrow. Cells were maintained in $7 \mathrm{ml}$ of balanced salt solution. $B$, The cell was exposed to $100 \mu \mathrm{M}$ nicotine in the absence and presence of $\mathrm{Ca}^{2+}$. Cells were maintained in a $\mathrm{Ca}^{2+}$-free balanced salt solution. Arrows: $a, 3 \mathrm{sec}$ application of $100 \mu \mathrm{M}$ nicotine without $\mathrm{Ca}^{2+} ; b, 3 \mathrm{sec}$ application of $100 \mu \mathrm{M}$ nicotine with $2.0 \mathrm{mM} \mathrm{Ca}^{2+}$. Detection was performed in the amperometric mode (constant potential) at $650 \mathrm{mV}$ versus SSCE.

in the injection solution evoked a series of rapid current responses.

\section{Repeated nicotine-stimulated catecholamine release from single cells}

To demonstrate the effect of autoreceptors on quantal release in the adrenal cell system, it is preferable to use the response to repeated nicotine stimulations of the same cell. Individual cells were repeatedly stimulated with 3 sec exposures to nicotine ( 100 $\mu \mathrm{M})$ at intervals of 100-400 sec. The current responses for neurohormone secretion were integrated to obtain the total charge for the response over a $200 \mathrm{sec}$ time window. Representative data are shown in Figure 2. For repetitive $3 \mathrm{sec}$ exposures to nicotine, the ratio of total secretion of the second to the first exposure $\left(\mathrm{S}_{2}: \mathrm{S}_{1}\right)$ is $0.32 \pm 0.05(n=7)$ and the ratio of total 


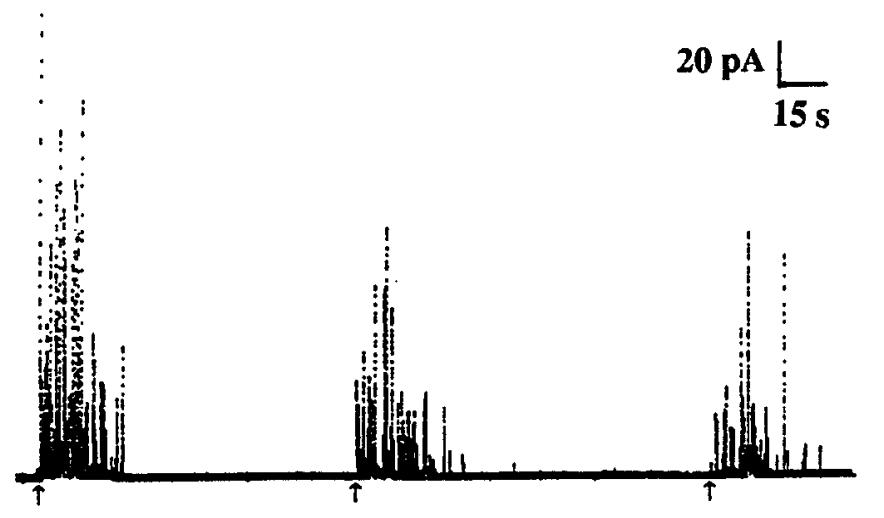

Figure 2. Amperometric response of one chromaffin cell to three successive $3 \mathrm{sec}$ applications of $100 \mu \mathrm{M}$ nicotine at the arrows. Electrode potential was $650 \mathrm{mV}$ versus SSCE.

secretion of the third to the second exposure $\left(\mathrm{S}_{3}: \mathrm{S}_{2}\right)$ is $0.80 \pm$ $0.02(n=4)$.

\section{Effects of piperoxan on nicotine-stimulated catecholamine releàse from single cells}

The effects of autoreceptors on single adrenal medullary chromaffin cells were characterized by $5 \mathrm{sec}$ applications of piperoxan $(20 \mu \mathrm{M})$ approximately $80 \mathrm{sec}$ after a $3 \mathrm{sec}$ injection of nicotine. A representative experiment is shown in Figure $3 \mathrm{~A}$. After a $3 \mathrm{sec}$ application of nicotine, the characteristic current response showing a large number of oxidation spikes is observed. At approximately $80 \mathrm{sec}$ after the stimulation, the occurrence of oxidation spikes has significantly decreased. At this point, application of $20 \mu \mathrm{M}$ piperoxan results in a significant increase in the oxidation spikes observed. A second 5 sec application of $20 \mu \mathrm{M}$ piperoxan after another $80 \mathrm{sec}$ interval again results in oxidation spikes, apparently indicating a resurgence of catecholamine release by exocytosis. Three additional $5 \mathrm{sec}$ applications of $20 \mu \mathrm{M}$ piperoxan resulted in very little increase in oxidation spikes. However, a final application of nicotine resulted a sharp increase in release events as observed by amperometry. A control experiment involving application of nicotine followed by only a balanced salt solution is shown in Figure $3 B$. The data in Figure $3 B$ are very similar to that obtained following only nicotine stimulation (Fig. $1 A$ ).

To evaluate the effect of piperoxan on catecholamine exocytosis, the integrated current for release events following nicotine and piperoxan together has been compared to the total charge for release events after only nicotine. This comparison is shown as a ratio of the total charge for all the current spikes after the sequence of nicotine and piperoxan stimulations to the total charge after only nicotine in Figure 4. A $15 \%(n=3)$ increase in catecholamine release is ohserved after the nicotine and piperoxan compared to a $46 \%(n=6)$ decrease in release for the control experiment (identical protocol without application of piperoxan).

\section{Effect of clonidine on nicotine-stimulated catecholamine release from single cells}

To demonstrate further the effect of autoreceptors on single adrenal medullary chromaffin cells, the response of stimulated release to an agonist was evaluated. Here, adrenal cells were incubated in culture medium containing $20 \mu \mathrm{M}$ clonidine for
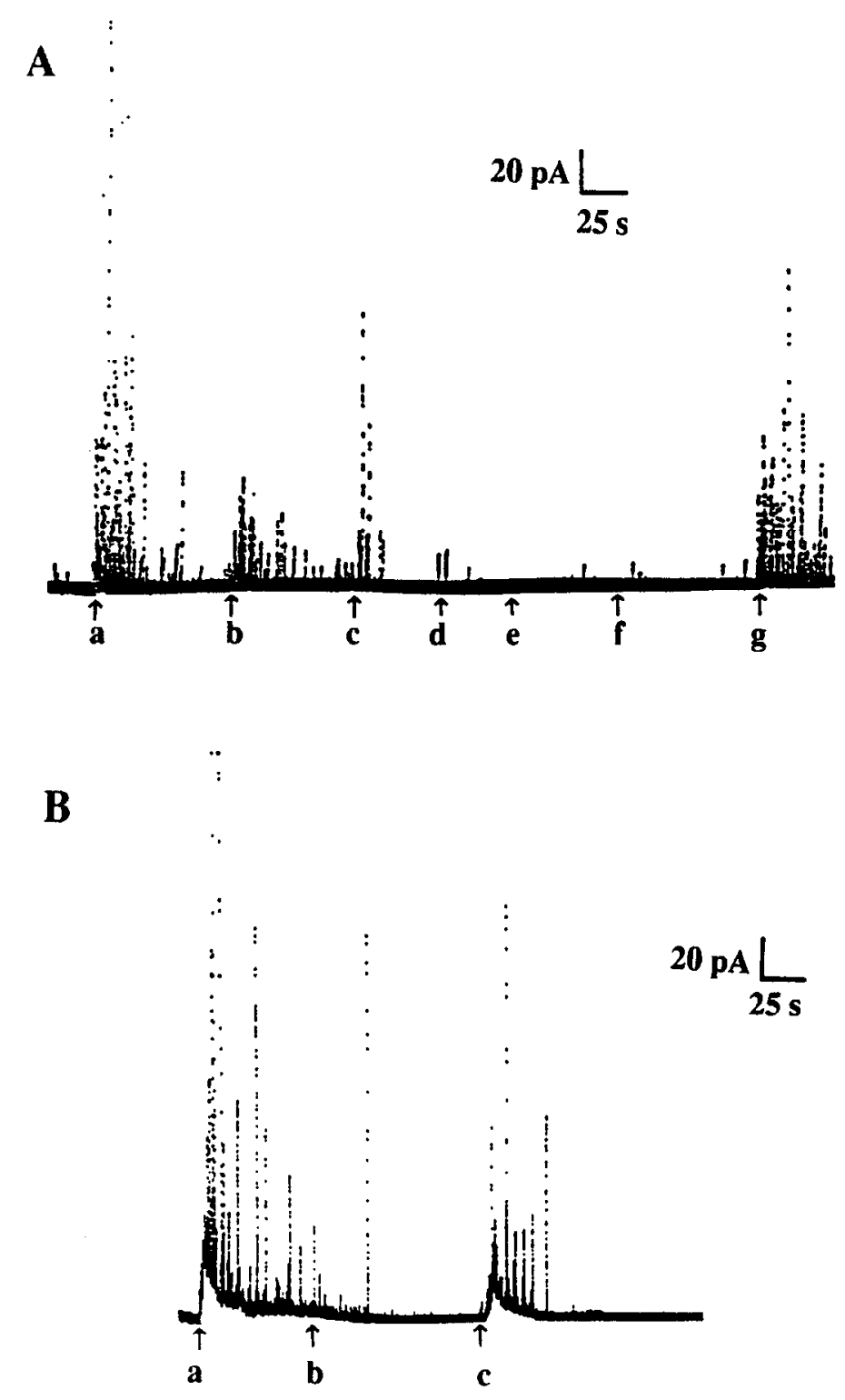

Figure 3. Effect of piperoxan ( $20 \mu \mathrm{M}$ on nicotine-induced exocytosis of catecholamines. $A: a$ and $g, 3 \mathrm{sec}$ application of $100 \mu \mathrm{M}$ nicotine; $b$ $f, 5 \mathrm{sec}$ application of $20 \mu \mathrm{M}$ piperoxan. $B: a$ and $c, 3 \mathrm{sec}$ application of $100 \mu \mathrm{M}$ nicotine. $b, 5 \mathrm{sec}$ application of balanced salt solution. Electrode potential was $650 \mathrm{mV}$ versus SSCE.

30-90 min and then stimulated with a $3 \mathrm{sec}$ injection of nicotine containing $20 \mu \mathrm{M}$ clonidine. The action of clonidine is slow and has little or no effect on stimulated release after transient application. The comparison between the total charge for catecholamine release events after incubation with clonidine to that of a control group without clonidine is shown in Figure 5. After incubation with clonidine for 30-60 min, secretion decreases $75 \%$ over the control group $(P<0.05)$. Secretion decreases $82 \%$ over the control group $(P<0.05)$ when a 90 min incubation with clonidine is used.

Effect of amphetamine on nicotine-stimulated catecholamine release from single cells

Amphetamine is thought to act via a mechanism that increases the extracellular concentration of catecholamines. Here, we have 


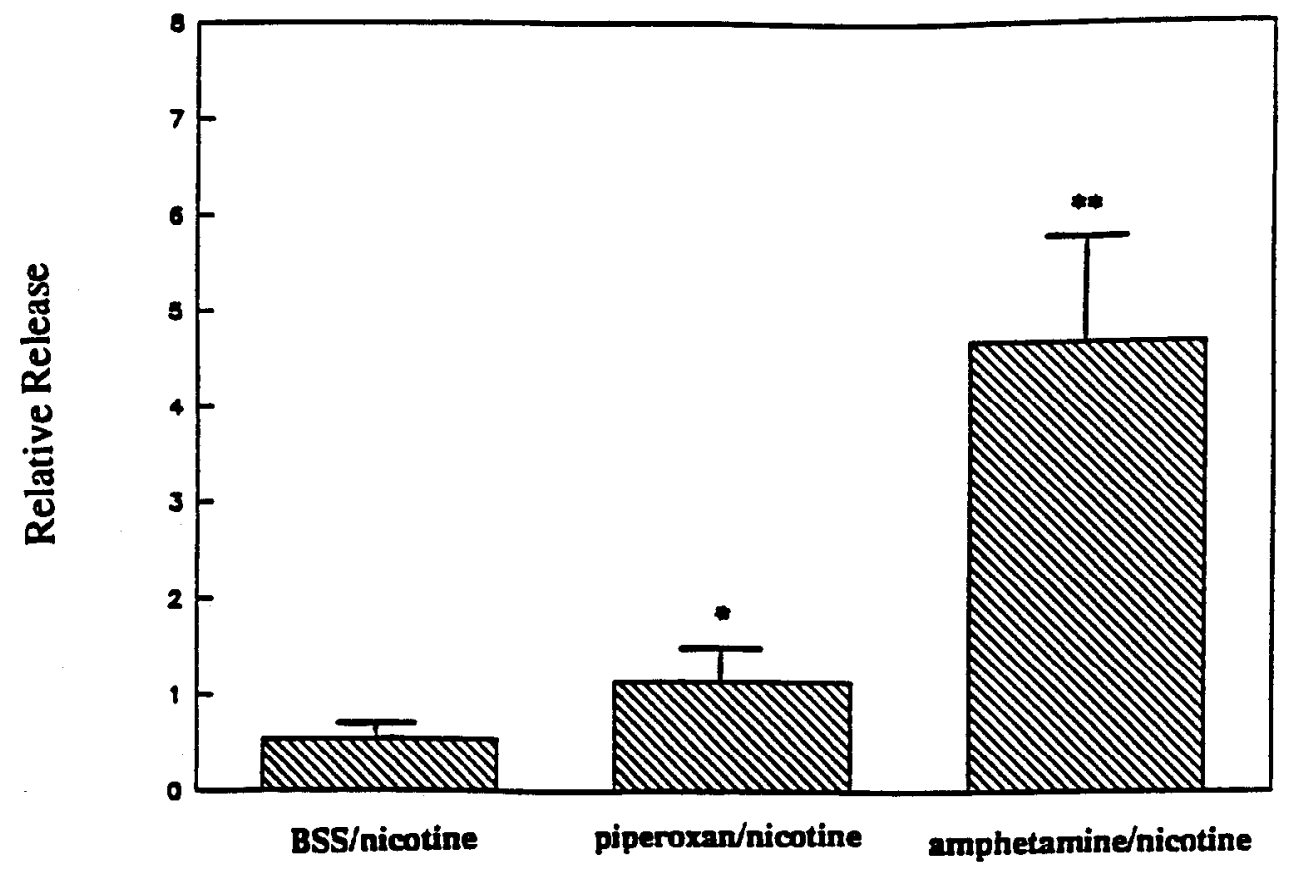

Figure 4. Effect of piperoxan $(20 \mu \mathrm{M})$ and amphetamine $(20 \mu \mathrm{M})$ on nicotinestimulated release. In each experiment, a $3 \mathrm{sec}$ application of $100 \mu \mathrm{M}$ nicotine was followed by a $5 \mathrm{sec}$ application of balanced salt solution $(B S S)(n=6), 20$ $\mu \mathrm{M}$ piperoxan $(n=3)$, or $20 \mu \mathrm{M}$ amphetamine $(n=3)$. Catecholamine release is expressed as the ratio of total charge for all release events (integrated current under all the spikes monitored) following nicotine and balanced salt solution, nicotine and piperoxan, or nicotine and amphetamine, relative to the total charge for all release events following nicotine only. Both piperoxan and amphetamine increase nicotinestimulated release significantly: ${ }^{*}, P<$ $0.05 ;{ }^{* *}, P<0.01$ ) examined the effect of amphetamine on release of catecholamines from cultured adrenal cells. A $5 \mathrm{sec}$ application of amphetamine $(20 \mu \mathrm{M})$ at approximately $20 \mathrm{sec}$ after stimulation of the cell with nicotine resulted in a dramatic increase in catecholamine release events (Fig. 6). A comparison of the ratio of total release following nicotine and amphetamine relative to nicotine only is included in Figure 4. The increase in catecholamine exocytosis (only the current under the current spikes is integrated) over the control experiment is $870 \%$.

\section{Discussion}

Voltammetry at microelectrodes can be used to monitor single exocytotic events at catecholamine containing adrenal medullary chromaffin cells (Leszczyszyn et al., 1990, 1991; Wightman et al., 1991). In the previous work, voltammetric and pharmacological evidence indicated that the amperometric signals observed were due to exocytosis of catecholamines. The amperometric response to nicotine stimulation is $\mathrm{Ca}^{2+}$ dependent and consists of a series of rapid current spikes when the electrode is held at a sufficient oxidation potential (Fig. 1). This is consistent with the requirement of $\mathrm{Ca}^{2+}$ for exocytosis (Douglas, 1968; Viveros, 1975; Schweizer et al., 1989). Assuming a twoelectron oxidation process, the quantity of charge in the average spike corresponds to the detection of $4 \times 10^{-18}$ mol of catecholamine. This value is in the range calculated for the average catecholamine vesicle in adrenal cclls (Winkler and Westhead, 1980; Wightman et al., 1991).

It is apparent from the data in Figure 2 that the total cate-

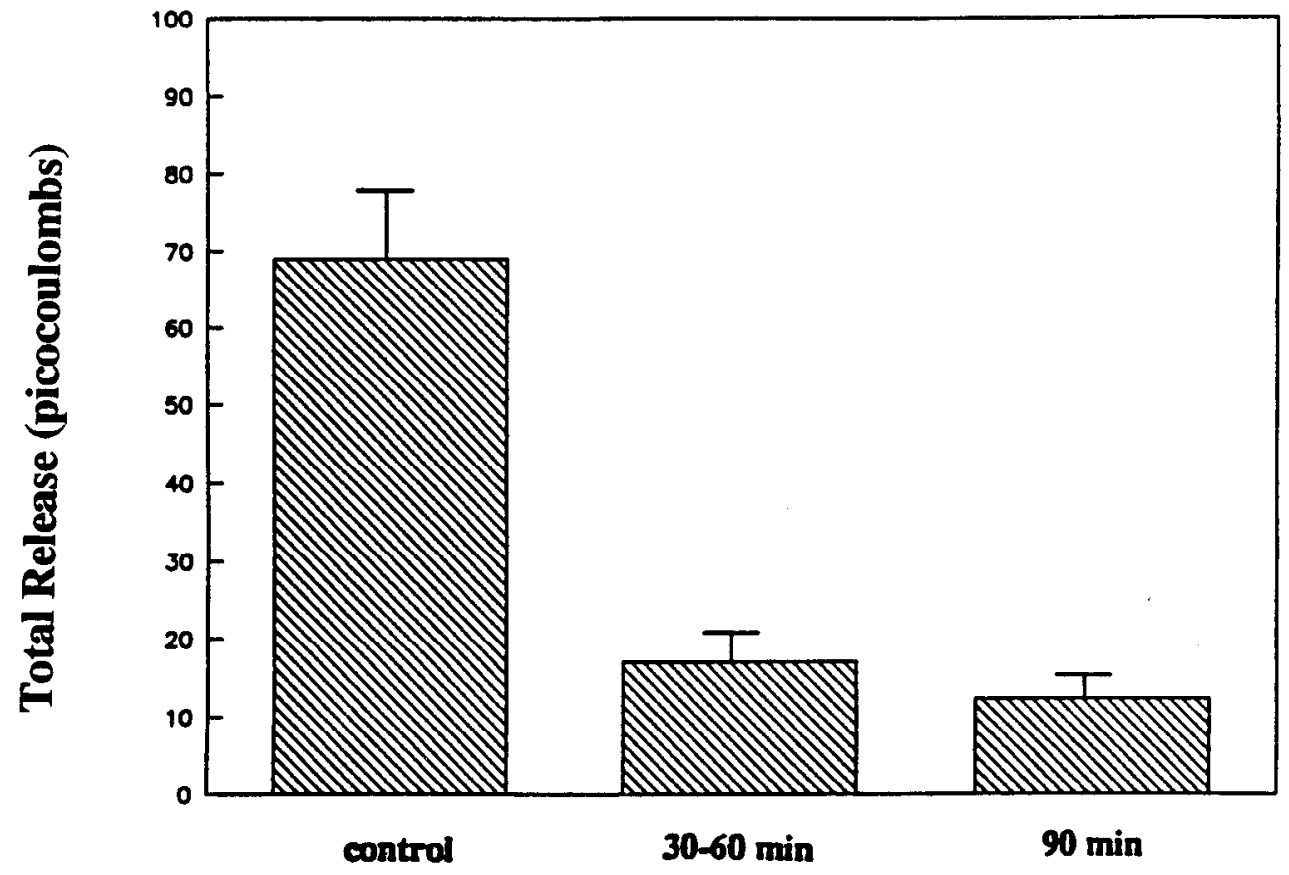

Figure 5. Effect of clonidinc $(20 \mu \mathrm{M})$ on nicotine-stimulated catecholamine release. The cells were incubated with clonidine for $30-60 \mathrm{~min}(n=4)$, or 90 $\min (n=4)$ and then stimulated with a $3 \mathrm{sec}$ injection of nicotine containing $20 \mu \mathrm{M}$ clonidine. The current responses for catecholamine release after the first nicotine stimulation were integrated to obtain the total charge. The total release decreased significantly after incubation with clonidine $(P<0.05)$ as compared to the control stimulations $(n=13)$. 


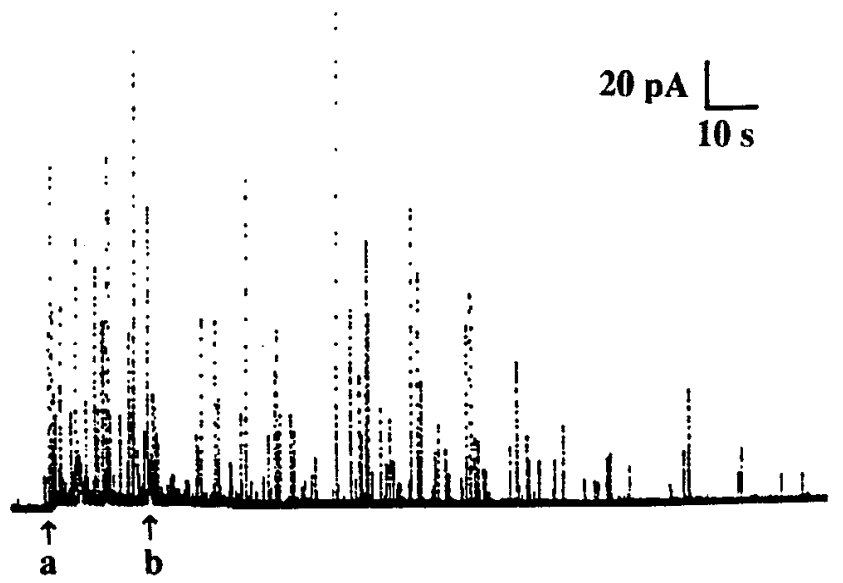

Figure 6. Amperometric response of a carbon-fiber electrode placed at a single chromaffin cell following a $3 \mathrm{sec}$ application of $100 \mu \mathrm{M}$ nicotine $(a)$, and a $5 \mathrm{sec}$ application of $20 \mu \mathrm{M}$ amphetamine $(b)$.

cholamine release (number of release events) from exocytosis following nicotine stimulation diminishes by $68 \%$ from the first to the second consecutive stimulation. From the second to the third stimulation only a $20 \%$ decrease in total release is observed. As shown below, this cannot be explained simply by depletion of catecholamine vesicles, but rather, appears to be the result of cell inhibition by autoreceptors.

To support the hypothesis that autoreceptors are activated by a threshold concentration of released neurotransmitter, the release of catecholamines has been estimated from overflow into an incubation or perfusion fluid (Langer, 1977; Langer et al., 1977; Starke, 1977, 1987; Langer and Dubocovich, 1981). The present work provides direct evidence for autoreceptors at the single-cell level and with millisecond time resolution. Although it has been reported that functional adrenoreceptors are not present on adrenal chromaffin cells (Powis and Baker, 1986; Orts et al., 1987), the results of repeated stimulation (Fig. 2) suggest that $\alpha_{2}$-autoreceptors do exist on the adrenal medullary chromaffin cells and act to decrease catecholamine release. The data in Figure 3 strongly suggest that a negative feedback mechanism exists. The first and second injections of piperoxan lead to the promotion of release spikes, but subsequent injections do not result in additional release. Apparently, the effects of the initial nicotine stimulation on the nicotinic receptors are diminished at these later times. Exposure to piperoxan enhances the release of the catecholamines from nicotine-stimulated cells; however, piperoxan alone has no effect upon on release from cells not exposed to nicotine. The final exposure to nicotine (Fig. 3) shows that both the cell and the microelectrode still responded to nicotine stimulation and the presence of catecholamines, respectively. Thus, the lack of release for piperoxan exposures labeled d-f in Figure 3 can be attributed to a lack of stimulation of the nicotinic receptors.

The effect of clonidine on stimulated release (Fig. 5) further suggests that there are autoreceptors on adrenal medullary chromaffin cells. After the cell is incubated with clonidine, the total catecholamine release declines significantly after the first $3 \mathrm{sec}$ application of nicotine. Apparently, the release of catecholamine is inhibited by autoreceptors activated by clonidine. The decrease of catecholamine release after incubation of cells with clonidine for $90 \mathrm{~min}$ compared to control group is greater (82\%) than the decrease after incubation of cells for 30-60 min (75\%). This suggests that the effect of clonidine is slow and agrees with the hypothesis that clonidine stimulation of autoreceptors results in the inhibition of catecholamine synthesis (Feldman and Quenzer, 1984).

Perhaps the most widely known sympathomimetic drug is amphetamine. The actions of amphetamine appear to be manifested as an increased level of extracellular catecholamine in regions of the CNS (Zetterström et al., 1983; Hernandez et al., 1987; Sharp et al., 1987). A great deal of work has shown that amphetamine enhances release of catecholamines (Kuczenski, 1983), inhibits the catecholamine transporter (Wise and Bozarth, 1987), and accelerates exchange diffusion across the plasma membrane (Fischer and Cho, 1979; Kuczenski, 1983). In addition, recent evidence suggests that amphetamine acts as a weak base to disrupt catecholamine vesicularization, and therefore enhance the cytoplasmic level of neurotransmitter for subsequent release via reverse transport (Sulzer and Rayport, 1990). All these actions appear to play a role in the response to amphetamine. The data presented in this article point to a specific mechanism whereby amphetamine can also increase extracellular catecholamine levels via an increase in exocytotic release by acting as an antagonist on $\alpha_{2}$-autoreceptors. This appears to be completely consistent with data suggesting that amphetamine does not bind strongly to the catecholamine transporter (Andersen, 1987; Ritz et al., 1987). However, the data are not consistent with studies showing an effect of amphetamine due to binding at dopamine receptors (Shalaby et al., 1983; Kuczenski et al., 1990). This might reflect a specific difference in action between $\mathrm{D}_{2}$ and $\alpha_{2}$-autoreceptors. Blockade of $\alpha_{2}$-autoreceptors leading to enhanced release increases the extracellular level of catecholamine, which is the clear end result of amphetamine administration.

\section{References}

Abercrombie ED, Keller RM, Zigmond MJ (1988) Characterization of hippocampal norepinephrine release as measured by microdialysis perfusion: pharmacological and behavioral studies. Neuroscience 27: 897-904.

Andersen PH (1987) Biochemical and pharmacological characterization of [ $\left.{ }^{1} \mathrm{H}\right] \mathrm{GBR} 12935$ binding in vitro to rat striatal membranes; labeling of the dopamine uptake complex. J Neurochem 48:18871896.

Cooper JR, Bloom FE, Roth RH (1991) The biochemical basis of neuropharmacology. New York: Oxford UP.

Dennis T, L'Heureux R, Carter C, Scatton B (1987) Presynaptic $\alpha_{2}$ adrenoreceptors play a major role in the effects of idazoxan on cortical noradrenaline release (as measured by in vivo dialysis) in the rat. J Pharmacol Exp Ther 241:642-649.

Douglas WW (1968) Stimulus-secretion coupling: the concept and clues from chromaffin and other cells. Br J Pharmacol 34:451-474.

Feldman RS, Quenzer LF (1984) Fundamentals of neuropsychopharmacology, p 189. Sunderland, MA: Sinauer.

Fischer JF, Cho AK (1979) Chemical release of dopamine from striatal homogenatcs: cvidence for an exchange diffusion model. J Pharmacol Exp Ther 208:203-209.

Hernandez L, Lee F, Hoebel BG (1987) Simultaneous microdialysis and amphetamine infusion in the nucleus accumbens and striatum of freely moving rats: increase in extracellular dopamine and serotonin. Brain Res Bull 19:623-628.

Jackisch R, Huang HY, Rensing H, Lauth D, Allgaier C, Hertting G (1992) $\alpha_{2}$-Adrenoceptor mediated inhibition of exocytotic noradrenaline release in the absence of extracellular calcium. Eur J Pharmacol $8: 245-252$.

Kelly RS, Wightman RM (1986) Bevelled carbon-fiber ultramicroelectrodes. Anal Chim Acta 187:79-87.

Kuczenski R (1983) Biochemical actions of amphetamine and other 
stimulants. In: Stimulants: neurochemical, behavioral, and clinical perspectives (Creese I, ed), pp 31-61. New York: Raven.

Kuczenski R, Segal DS, Manley LD (1990) Apomorphine does not alter amphetamine-induced dopamine release measured in striatal dialysates. J Neurochem 54:1492-1499.

Langer SZ (1977) Presynaptic receptors and their role in the regulation of transmitter release. Br J Pharmacol 60:481-497.

Langer SZ, Dubocovich ML (1981) Cocaine and amphetamine antagonize the decrease of noradrenergic neurotransmission elicited by oxymetazoline but potentiate the inhibition by $\alpha$-mcthylnorcpincphrine in the perfused cat spleen. J Pharmacol Exp Ther 216:162171.

Langer SZ, Adler-Graschinsky E, Giorgi O (1977) Physiological significance of $\alpha$-adrenoceptor-mediated negative feedback mechanism regulating noradrenaline release during nerve stimulation. Nature 265 : $648-650$.

Leszczyszyn DJ, Jankowski JA, Vieros OH, Diliberto EJ Jr, Near JA, Wightman RM (1990) Nicotine receptor-mediated catecholamine secretion from individual chromaffin cell: chemical evidence for exocytosis. J Biol Chem 265:14736-14737.

Leszczyszyn DJ, Jankowski JA, Viveros OH, Diliberto EJ Jr, Near JA Wightman RM (1991) Secretion of catecholamines from individual adrenal medullary chromaffin cells. J Neurochem 56:1855-1863.

Livett BG (1984) Adrenal medullary chromaffin cells in vitro. Physiol Rev 64:1103-1160.

Orts A, Orellana C, Canto T, Cena V, Gonzalez-Garcia C, Garcia AG (1987) Inhibition of adrenomedullary catecholamine release by propranolol isomers and clonidine involving mechanisms unrelated to adrenoreceptors. Br J Pharmacol 92:795-801.

Pelayo F, Dubocovich ML, Langer SZ (1980) Inhibition of neuronal uptake reduces the presynaptic effects of clonidine but not $\alpha$-methylnoradrenaline on the stimulation-evoked release of ${ }^{3} \mathrm{H}$-noradrenaline from rat occipital cortex slices. Eur J Pharmacol 64:143-155.

Powis DA, Baker PF (1986) $\alpha_{2}$-Adrenoceptors do not regulate catecholamine secretion by bovine adrenal medullary cells: a study with clonidine. Mol Pharmacol 29:134-141.

Ritz MC, Lamb RJ, Goldberg SR, Kuhar MJ (1987) Cocaine receptors on dopaminc transporters are related to self-administration of cocaine. Science 237:1219-1223.

Schweizer FE, Schafer T, Tapparelli C, Crob M, Karli UO, Heumann
R, Thoenen H, Bookman RJ, Burger MM (1989) Inhibition of exocytosis by intracellularly applied antibodies against a chromaffin granule-binding protein. Nature 339:709-712.

Shalaby IA, Kotake C, Hoffmann PC, Heller A (1983) Release of dopamine from coaggregate cultures of mesencephalic tegmentum and corpus striatum. J Neurosci 3:1565-1571.

Sharp T, Zetterström T, Ljungbers T, Ungerstedt U (1987) A direct comparison of amphetamine-induced behaviours and regional brain dopamine release in the rat using intracerebral dialysis. Brain Res 401:322-330.

Starke K (1977) Regulation of noradrenaline release by presynaptic receptor systems. Rev Physiol Biochem Pharmacol 77:1-124.

Starke K (1981) Presynaptic receptors. Annu Rev Pharmacol Toxicol 21:7-30.

Starke K (1987) Presynaptic $\alpha$-autoreceptors. Rev Physiol Biochem Pharmacol 107:73-146.

Sulzer D, Rayport S (1990) Amphetamine and other psychostimulants reduce $\mathrm{pH}$ gradients in midbrain dopaminergic neurons and chromaffin granules: a mechanism of action. Neuron 5:797-808.

Viveros OH (1975) Handbook of physiology, section on endocrinology, Vol 6 (Blaschko A, Smith AD, eds), pp 389-426. Washington, DC: American Physiological Society.

Westfall TC (1977) Local regulation of adrenergic neurotransmission. Physiol Rev 57:659-728.

Wightman RM, Jankowski JA, Kennedy RT, Kawagoe KT, Schroeder TJ, Leszczyszyn DJ, Near JA, Diliberto EJ Jr, Viveros OH (1991) Temporally resolved catecholamine spikes correspond to single vesicle release from individual chromaffin cells. Neurobiology 88:10754 10758.

Wilson SP, Viveros OH (1981) Primary culture of adrenal medullary chromaffin cells in a chemically defined medium. Exp Cell Res 133: 159-169.

Winkler M, Westhead E (1980) The molecular organization of adrenal chromaffin granules. Neuroscience 5:1803-1823.

Wise RA, Bozarth MA (1987) Brain mechanisms of drug reward and euphoria. Psychol Med 3:445-460.

Zetterström T, Sharp T, Marsden CA, Ungerstedt U (1983) In vivo mcasurcment of dopaminc and its metabolites by intracerebral dialysis: changes after $d$-amphetamine. J Neurochem 41:1769-1773. 